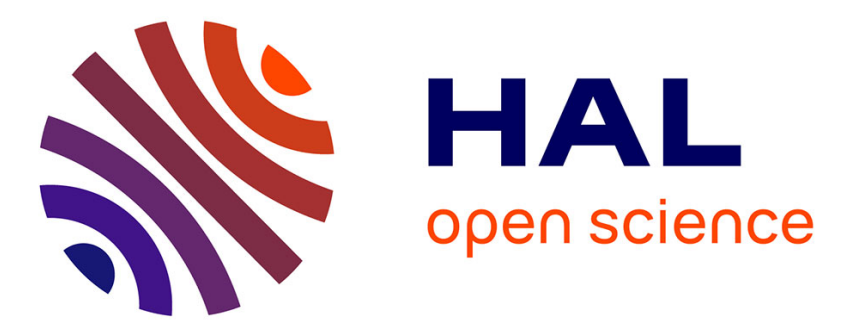

\title{
Human hepatic cell behavior on polysulfone membrane with double porosity level
}

Murielle Dufresne, Patrice Bacchin, Giulia Cerino, Jean-Christophe Remigy, Gerard Nathanael Adrianus, Pierre Aimar, Cécile Legallais

\section{To cite this version:}

Murielle Dufresne, Patrice Bacchin, Giulia Cerino, Jean-Christophe Remigy, Gerard Nathanael Adrianus, et al.. Human hepatic cell behavior on polysulfone membrane with double porosity level. Journal of Membrane Science, 2013, vol. 428, pp. 454-461. 10.1016/j.memsci.2012.10.041 • hal-00788387

\section{HAL Id: hal-00788387 \\ https://hal.science/hal-00788387}

Submitted on 14 Feb 2013

HAL is a multi-disciplinary open access archive for the deposit and dissemination of scientific research documents, whether they are published or not. The documents may come from teaching and research institutions in France or abroad, or from public or private research centers.
L'archive ouverte pluridisciplinaire HAL, est destinée au dépôt et à la diffusion de documents scientifiques de niveau recherche, publiés ou non, émanant des établissements d'enseignement et de recherche français ou étrangers, des laboratoires publics ou privés. 


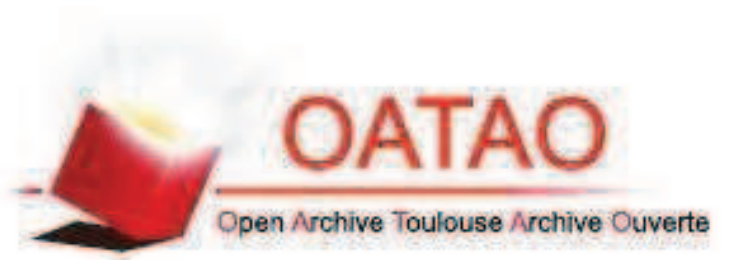

\section{Open Archive Toulouse Archive Ouverte (OATAO)}

OATAO is an open access repository that collects the work of Toulouse researchers and makes it freely available over the web where possible.

This is an author-deposited version published in: http://oatao.univ-toulouse.fr/ Eprints ID: 8286

To link to this article: DOI: $10.1016 /$ j.memsci.2012.10.041

URL : http://dx.doi.org/10.1016/j.memsci.2012.10.041

\section{To cite this version:}

Dufresne, Murielle and Bacchin, Patrice and Cerino, Giulia and Remigy, JeanChristophe and Adrianus, G.N. and Aimar, Pierre and Legallais, Cécile Human hepatic cell behavior on polysulfone membrane with double porosity level. (2013) Journal of Membrane Science, vol. 428 . pp. 454-461. ISSN 0376-7388 


\title{
Human hepatic cell behavior on polysulfone membrane with double porosity level
}

\author{
M. Dufresne ${ }^{a}$, P. Bacchin ${ }^{\mathrm{b}}$, G. Cerino ${ }^{\mathrm{a}}$, J.C. Remigy ${ }^{\mathrm{b}}$, G.N. Adrianus ${ }^{\mathrm{a}}$, P. Aimar ${ }^{\mathrm{b}}$, C. Legallais ${ }^{\mathrm{a}, *}$ \\ a UMR CNRS 7338, Biomechanics and Bioengineering, University of Technology of Compiègne, Royallieu Research Center, BP 60529, 60205 Compiègne, France \\ b University Paul Sabatier, Laboratory of Chemical Engineering, UMR CNRS 5503, Toulouse, France
}

Keywords:

Polysulfone membrane

Porosity

Hepatic cell

Bioartificial liver

Biocompatibility

\begin{abstract}
A B S T R A C T
In the membrane-based bioartificial livers developed up to now, the hepatic cells were located either in the fibers' lumen or in the cartridge, with limited capacity for cell hosting. Here, we designed a polysulfone (PSU) membrane with a double porosity level: (i) surface macroporosity emerging in macrochambers accessible to hepatic cell colonization; (ii) microporosity to ensure gas and molecule transfers between macrochambers and supernatant, as well as potential immune barrier. ESEM and X-ray tomography confirmed that macrochambers accessed the membrane surface and were interconnected. Biocompatibility and performances of this PSU membrane with double porosity level were compared to classical semi-permeable structures, following cell organization, cell proliferation and liver specific activities over a 9 days incubation. Macrochambers were colonized by hepatic cells, leading to higher albumin synthesis compared to control. Therefore, this membrane with double porosity appeared as a promising support to offer an inner 3D environment adequate to cell proliferation to form a liver-like tissue.
\end{abstract}

\section{Introduction}

Polysulfone (PSU) and derived polymers are commonly used to elaborate synthetic membranes for extracorporeal blood filtration systems. PSU filters offer a broad spectrum of properties in agreement with different therapy modalities, combining high mass transfers with hemocompatibility in clinical applications (hemodialysis, plasmafractionation or plasmapheresis) [1,2]. The success of this polymer can be explained by an adaptable porosity of the membrane which selectively filters solutes and wastes from plasma whilst retaining blood cells and proteins of interest in the circulatory compartment $[3,4]$.

PSU supports present several other advantages over many polymers which are suitable for artificial systems in medical studies [5]. PSU is a biocompatible polymer whose properties allow the fabrication of different support geometries such as flat membranes or hollow fibers. PSU polymer, which results from a polycondensation, is stable in physiological conditions with a good chemical resistance. Its stability to steam should be noted, making sterilization possible by this largely used procedure. Its

\footnotetext{
* Corresponding author. Tel.: +33 3442344 01; fax: +33 344237942

E-mail addresses: murielle.dufresne@utc.fr (M. Dufresne),

bacchin@chimie.ups-tlse.fr (P. Bacchin), giulia.cerino@polito.it (G. Cerino), remigy@chimie.ups-tlse.fr (J.C. Remigy),

adrianus_setiawan@yahoo.com (G.N. Adrianus)

aimar@chimie.ups-tlse.fr (P. Aimar), cecile.legallais@utc.fr (C. Legallais).
}

hydrophobic and apolar properties favor the serum protein adsorption, even if non-specific protein adsorption is limited on PSU compared to other hydrophobic membranes [6]. Particularly, PSU membrane bound a small proportion of albumin while retaining protein associated with the coagulation cascade [7]. To reduce protein adsorption, PSU can be mixed to a water-miscible organic solvent to increase polymer wettability and viscosity. Polyvinylpyrrolidone (PVP) or N-methyl-2-pyrrolidone (NMP) are currently added to modify PSU in biomedical applications, then increasing the wettability of the polymer and reducing platelet adhesion on the surface $[8,9]$.

In medical applications, PSU has been used for bioartificial liver (BAL) design [10]. BALs aim at replacing metabolic functions of the failing liver (such as biotransformation and protein synthesis) by hepatocyte incorporation in artificial systems. Thanks to its physical, chemical and biological properties, PSU (modified or not) membrane is then a material of choice in tissue engineered BAL. Some of them have been experimented through clinical trials, such as HepatAssist, MELS, AMC-BAL systems [10]. The PSU scaffold supports or is in close contact with liver cells. The choice of scaffold design is crucial and must provide a structured environment with tissue-specific mechanical properties to receive living cells [11]. The cells cultivated in this 3D configuration present morphological and physiological characteristics which are closely related to tissue-like structure and functionality. Moreover, scaffold architecture has to respond to the need of hosting large cell amounts to support and bridge 
injured livers before self-regeneration or transplantation. The major limitation in engineering biosupports to enhance cell density comes from the thickness of growing tissue which gives rise to diffusion constraints. Oxygen and nutrient supply is necessary to maintain living cells and the scaffold design has to limit the distance between each cell and plasma or blood compartment, to favor both metabolite and waste exchanges [12].

To circumvent these limitations, several configurations were proposed in the past: high perfusion flow rate and use of a microporous membrane in the case of HepatAssist, or use of three types of hemofiltration membranes complexly woven in the case of MELS. Rather than the membrane itself, the module design or the perfusion process was optimized.

To improve the performances of membranes themselves, we propose here a new structure of PSU membrane to promote the cell density by offering a 3D architecture for growing cells while favouring gas and metabolite diffusion, between cells and medium supply on the one hand and among cells on the another one. This double property relies on two levels of porosity: a macroporosity that could favor the growth and activities of hepatocytes by encouraging close contact between cells and a microporosity to modulate gas and molecule transfers between each macrochamber and between macrochambers and compartment supply. Our approach consisted in following the behavior of a hepatocarcinoma cell line, C3A cells, cultivated in contact with two types of polysulfone membranes, the first one with double porosity level, and the second one, used as control, with microporosity only.

\section{Materials and methods}

\subsection{Fabrication of membranes}

The membranes were prepared using a modified phase inversion technique as shown in Fig. 1. A polymer solution was prepared by dissolving polysulfone (PSU, Udel P3500, Solvay) in $\mathrm{N}$-methyl-2-pyrrolidone (NMP) at $60^{\circ} \mathrm{C}$ during $24 \mathrm{~h}$. The concentration of PSU was set to $15 \%$ (wt). The polymer solution, at $20^{\circ} \mathrm{C}$, was poured on a glass tape using a gardener knife to reach a thickness about $250 \mu \mathrm{m}$. Two areas could be identified, covered or not by the polyester track etched membrane (Sterlitech, USA). Pore size of the track etched membrane was $10 \mu \mathrm{m}$. The track etched membrane was first immersed in NMP in order to fill the pores with NMP and was gently wiped to remove the excess of NMP.

The glass plate was then immersed in a bath of water in $20^{\circ} \mathrm{C}$. During the immersion, solvent exchange (both water and NMP) occurred leading to the coagulation of the polymer and the formation of the membrane. The solvent exchange was rather homogeneous in the zone where the polymer solution was in direct contact with the water whereas this exchange was localized within the pores of the track etched membrane in the zone where the polymer was covered up with the polyester membrane.

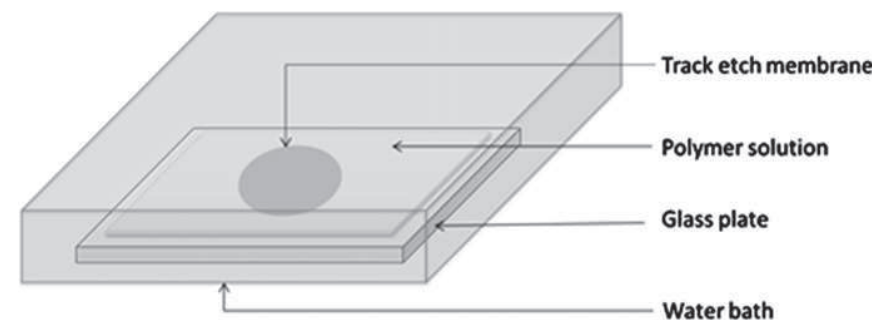

Fig. 1. PSU membranes preparation. The polymer solution was poured on a glass tape and a polyester track etched membranes was put at the surface of the polymer solution.
With this method, two types of membrane were prepared in the same condition. The part of the final membrane in direct contact with water presented a homogeneous microporous structure obtained with the classical technique of phase inversion by immersion in non-solvent. The rest of the membrane, where the polymer solution was covered up with the track etched membrane, had two porosity levels: the localized arrival of nonsolvent in the polymer solution induced the formation of large macrochambers in the microporous membrane surface.

After the formation of the membrane, the track etched membrane was removed and both types of membrane were separated and washed in water milliQ to remove possible residues. Squares of $1 \mathrm{~cm}^{2}$ were cut, sterilized in autoclave and stored in $4{ }^{\circ} \mathrm{C}$ until cell seeding.

\subsection{Structural characterization of membrane}

The structural characterization was performed using environmental scanning electron microscopy (ESEM) and X-ray tomography in order to study the membrane at different scales and dimensions (2D or 3D). A ESEM-FEG XL30 (Philips, France) was used for ESEM in a classical way. The ESEM allowed studying the structure in $2 \mathrm{D}$ with a high resolution. Pore size down to $10 \mathrm{~nm}$ could be observed but in a small sample size, typically far below $1 \mathrm{~mm}$. Complementary, X-ray tomography allowed the observation of 3D structure of large sample size but at low resolution. The resolution was directly linked to the sample size: high resolution allowed observing, in $3 \mathrm{D}$, pore size down to $1-3 \mu \mathrm{m}$ for a sample size in millimeter range [13]. We used a nanofocus computed tomography system NANOTOM ${ }^{\circledR}$ (GE Phoenix, Germany). The samples were dried at room temperature. About 1800 images were taken around the sample and a voxel size of around $2.2 \mu \mathrm{m}$ was reached so the smallest pore size that can be directly observed is $2.2 \mu \mathrm{m}$. A 3D volume of about $1962 \times 1659 \times 612 \mu \mathrm{m}^{3}$ was reconstructed using the GE Phoenix software provided with the device. Amira ${ }^{\circledR}$ software was used to visualize the 3D volume and to separate the solid and void phases.

\subsection{Cell culture}

C3A human hepatocellular carcinoma cells provided by the American Type Culture Collection (ATCC, reference CRL 10-741, LGC Standards Sarl, Molsheim, France or http://www.lgcstandard s-atcc.org/) were used. Cells were cultivated in Minimum Essential Medium Earle's salts (MEM) supplemented with 1\% L-glutamine $(200 \mathrm{mM}), 0.5 \%$ penicillin-streptomycin $(10,000 \mathrm{units} / \mathrm{mL}$ and $10,000 \mu \mathrm{g} / \mathrm{mL}$, respectively), $1 \%$ non-essential amino acids $(10 \mathrm{mM}), 1 \%$ HEPES buffer solution $(1 \mathrm{M}), 1 \%$ sodium pyruvate (100 mM) and 10\% fetal calf serum, from Gibco (Cergy Pontoise, France), in $37{ }^{\circ} \mathrm{C}$ and $5 \% \mathrm{CO}_{2}$ in a humidified atmosphere. Cells were initially plated in T-flask for expansion until they reached $80 \%$ confluence, after which they were trypsinized using $0.05 \%$ trypsin in $1 \mathrm{mM}$ EDTA.

Cells were seeded on squares $\left(1 \mathrm{~cm}^{2}\right)$ of the membranes with double porosity, microporosity alone, and on Thermanox ( $\mathrm{Nunc}^{\mathrm{TM}}$ ) used as control at a density of $2 \times 10^{4}$ cells $/ \mathrm{cm}^{2}$ in $50 \mu \mathrm{L}$ of complete medium. After incubation overnight in $37{ }^{\circ} \mathrm{C}, 5 \% \mathrm{CO}_{2}$, $1 \mathrm{~mL}$ of complete medium was added on each well of 12 -well plates and changed every 2 or 3 days.

\subsection{Cell morphological characteristics with ESEM}

PSU membranes and Thermanox with C3A cells were fixed for 30 min with $2.5 \%$ glutaraldehyde in phosphate buffered saline (PBS) at $4{ }^{\circ} \mathrm{C}$ and washed twice with water. To observe the cell colonization within the porous structure of the PSU membranes, 
samples were broken after freezing in liquid nitrogen. The observations were performed with an environmental scanning electron microscope (ESEM-FEG XL30, Philips, France).

\subsection{Cell histology}

After 8 days of culture, PSU membranes with C3A cells were fixed as previously described. Samples were embedded in Tissue-Tek ${ }^{\circledR}$ and sectioned (10 $\mu \mathrm{m}$ thickness) in microtome (Jung Frigocut Leica 2800 E). Sections were stained with Methylene Blue $1 \%$ to visualize the cells under inverted light microscope (Leica DMLB 30T).

\subsection{Cell viability and proliferation}

The cytotoxicity of PSU membranes was evaluated on C3A cells by lactate deshydrogenase (LDH) activity. $200 \mu \mathrm{L}$ of MEM medium complemented with $1 \%$ fetal calf serum were added to each sample and incubated at $37{ }^{\circ} \mathrm{C}$, in a humidified $5 \% \mathrm{CO}_{2}$ air incubator. After $15 \mathrm{~h}$ of incubation, LDH activity in the medium was measured (kit Promega, France) to estimate cell cytotoxicity. Absorbance was expressed as a percentage of the maximum LDH release obtained by lysing the cells in the presence of $0.8 \%$ Triton $\mathrm{X}-100$.

The metabolic activity was investigated using a colorimetric test, Alamar Blue ${ }^{\circledR}$ cell viability assay. The principle of the Alamar Blue test rests on a fluorescent metabolic indicator, the resazurin, which is reduced by metabolically-active cells to the fluorescent compound, the resorufin. Alamar Blue reagent (10\%) was added to each membrane sample in complete medium and cells were incubated for $1 \mathrm{~h}$ at $37{ }^{\circ} \mathrm{C}$ in a $5 \% \mathrm{CO}_{2}$ atmosphere. The resulting fluorescence intensity was measured using a SpectraFluor Plus (TECAN, Switzerland) plate reader with an excitation wavelength of $560 \mathrm{~nm}$ and an emission wavelength of $595 \mathrm{~nm}$. MEM with $10 \%$ of Alamar Blue without cells was used as reagent blank for the fluorometric measurements.
Cell proliferation was measured after cell trypsinization and EDTA treatment, and cell counting was performed using a Malassez hemocytometer.

\subsection{Determination of albumin and ammonia removal consumption}

The secretion of albumin from C3A cells was measured by an enzyme-linked immunosorbent assay (ELISA). Goat anti-human albumin IgG antibodies were purchased from Cappel Laboratories (Cochrainville, France).

Ammonia concentration was determined with a biochemistry automatus (Konelab 20, Thermo, Cergy-Pontoise, France) using kits from Randox (Mauguio, France).

\subsection{Statistical analysis}

Statistical analysis was performed using the Kruskal-Wallis non-parametric test in order to compare the differences between groups. Differences were considered as significant when $p<0.05$ and are identified by $*$. The results are expressed as mean \pm standard deviation of the mean. Each experiment was independently repeated 3 times for the cell viability and proliferation assays, and 2 times for the cell functionality tests.

\section{Results}

\subsection{Structural characteristics of membranes}

The surface and cross section characteristics of membranes were investigated by ESEM and X-ray tomography (Figs. 2 and 3). Fig. 2 shows the 3D reconstructed volumes of the two types of membrane. For both, two images are presented: the reconstructed volume (Fig. 2a, b) and for double porosity membrane, the one with a section near macrochambers (Fig. 2c).

The cross section of the single porosity membrane demonstrated a typical asymmetric structure formed by finger-like voids
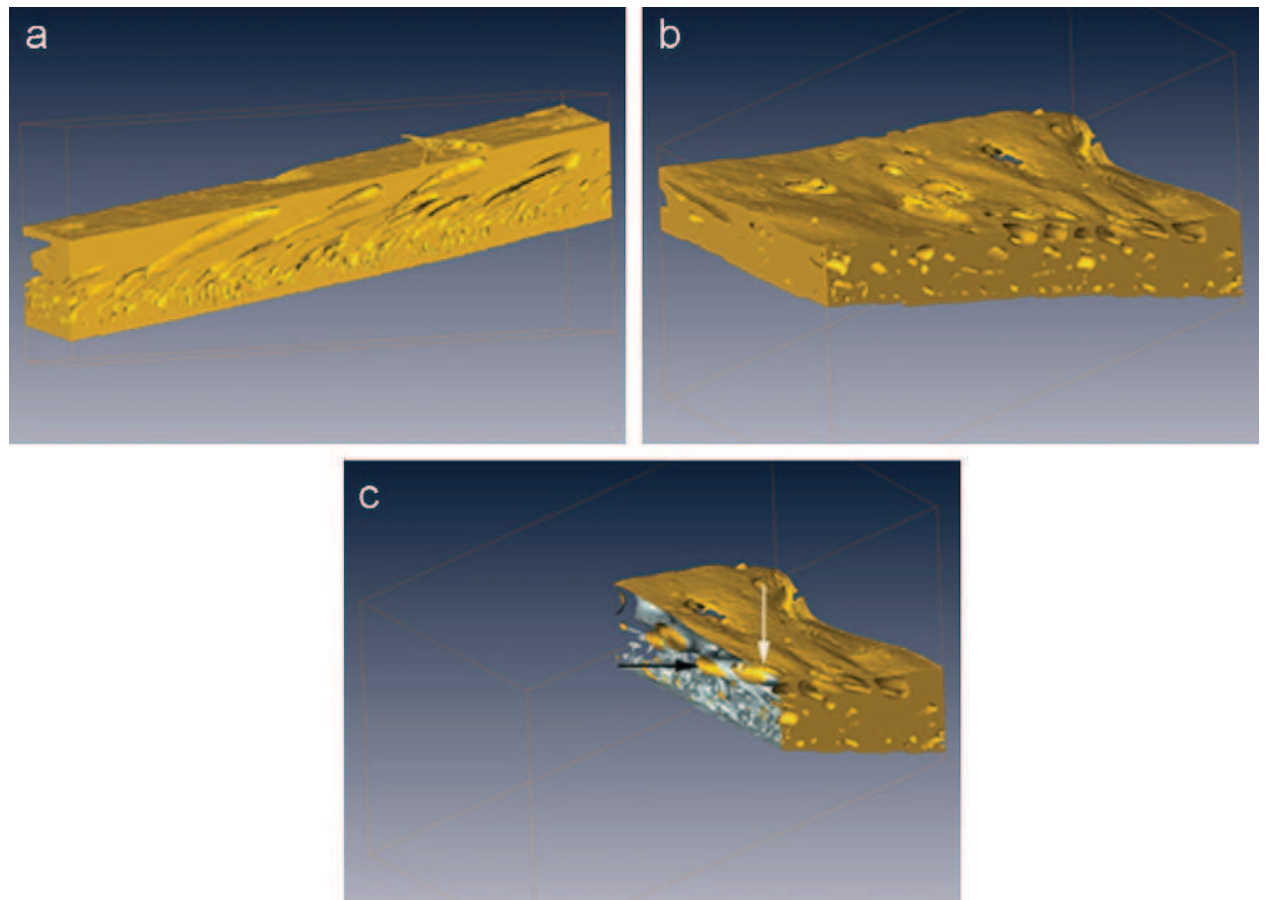

Fig. 2. X-ray tomography virtual cross-sections of membranes with (a) single porosity and (b, c) double porosity at the upper surface. The white arrow indicates macrochamber pore and the black arrow the $3 D$ connections between macrochambers. Gray box size (a) $201 \times 526 \times 78$ voxels or $442 \times 1157 \times 172 \mu m^{3}$ (b) and $(c)$ $591 \times 314 \times 278$ voxels or $1300 \times 691 \times 612 \mu \mathrm{m}^{3}$. 

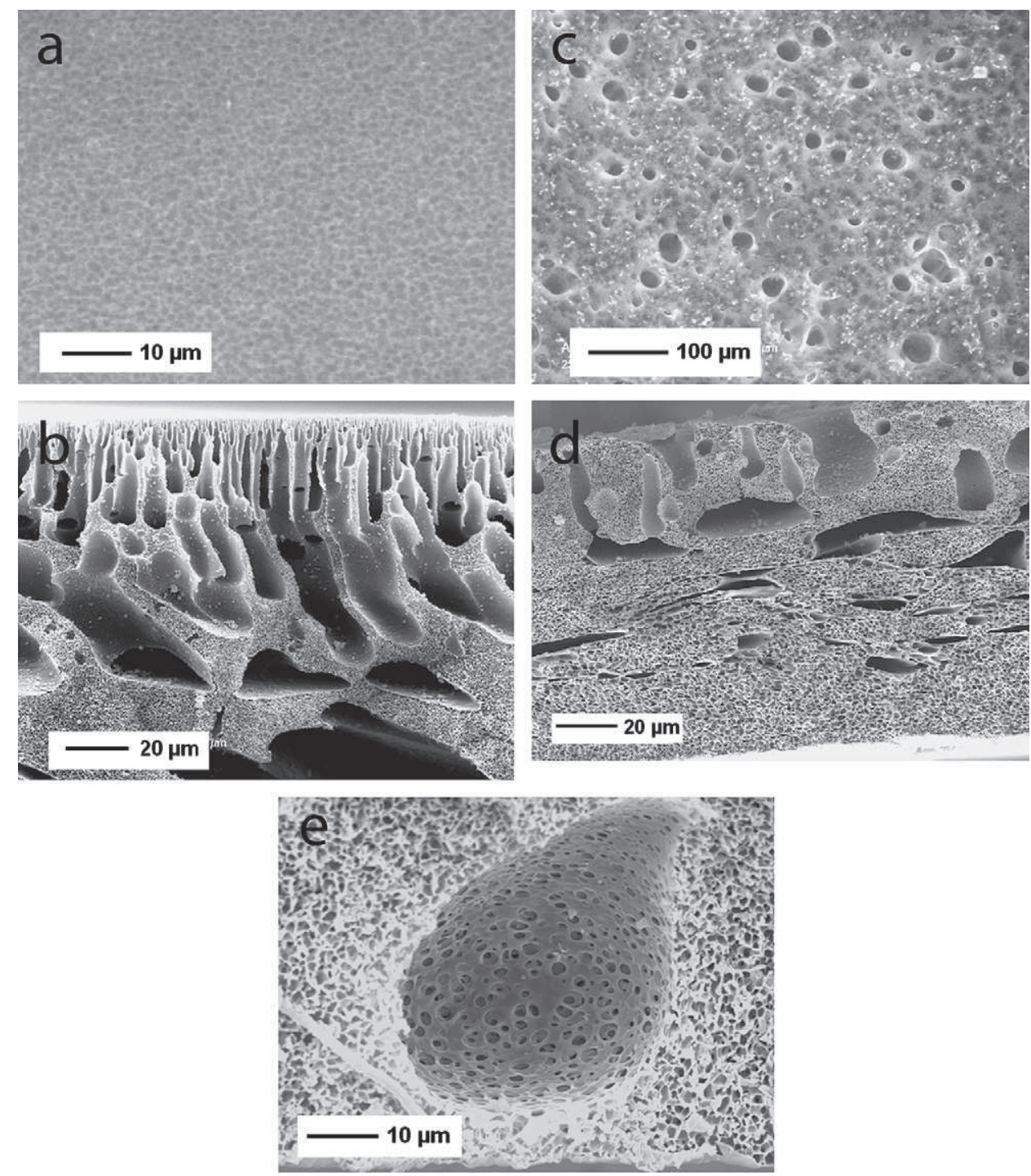

Fig. 3. ESEM micrographs of membranes with (a, b) single porosity, (c,d,e) double porosity showing (a, c) top of view of active layer, (b, d) cross section of membranes, and (e) macrochamber with high magnification.

(Fig. 2a). A denser layer was oriented to the active surface by open fingers at the micrometric scale (Fig. 3b). These microfinger-like structures were prolonged in deeper layer by macrofinger-like chambers, which walls were highly porous and without direct connection to the active surface. The top view surface (Fig. 3a) was homogeneously recovered by micropores whose diameters, calculated by ESEM, were $1.0 \pm 0.2 \mu \mathrm{m}$.

On the contrary, the asymmetrical structure of double porosity membrane, as observed by tomography (Fig. 2b, c), presented macrochambers which were largely open towards the active surface. Cross section photograph from ESEM (Fig. 3d) with higher resolution revealed that a third part of the membrane thickness was filled by macrochambers and confirmed their direct opening at the surface. The macrochambers displayed on a length of about $70 \mu \mathrm{m}$, to $200-300 \mu \mathrm{m}$ when oriented subhorizontally, for a diameter in the order of $50-60 \mu \mathrm{m}$. The macrochamber wall possessed a highly porous, sponge-like structure visible in Fig. 3e, with interconnected pores of a diameter in the range of $1 \mu \mathrm{m}$. The top view of the membrane with double porosity presented a rough surface with uniformly distributed pores (Fig. 3c). The mean pore diameter was about $50 \mu \mathrm{m}$ and most of pore sizes were above $20 \mu \mathrm{m}$.
The thickness of membrane with double porosity was about $180 \mu \mathrm{m}$ whereas that of membrane with single porosity was about $110 \mu \mathrm{m}$ (Fig. 2).

\subsection{Cell morphology, viability and proliferation}

Hepatic cells were cultivated on the PSU membanes with single or double porosity to follow the cellular distribution, morphology and physiology over 9 days. Thermanox was used as control for standard culture condition.

After few hours, hepatic cells attached and started proliferation on the surface of two types of membrane as they did on Thermanox. At day 8, hepatic cells formed a homogeneous layer at high cell density with tight cell-cell contact (Fig. 4a, b). The hepatocyte viability, estimated by LDH assay, was above $96 \%$ on two types of membranes, or on control, whatever the delay of culture (Fig. 6a).

Hepatic cell growth was measured by cell counting after detachment using trypsin. Cells appeared to proliferate equally on the membranes with double or single porosity, reaching the confluence state after 8 days (Fig. 6b). Similar data were obtained on Thermanox, although a slightly higher growth of about $20 \%$, 

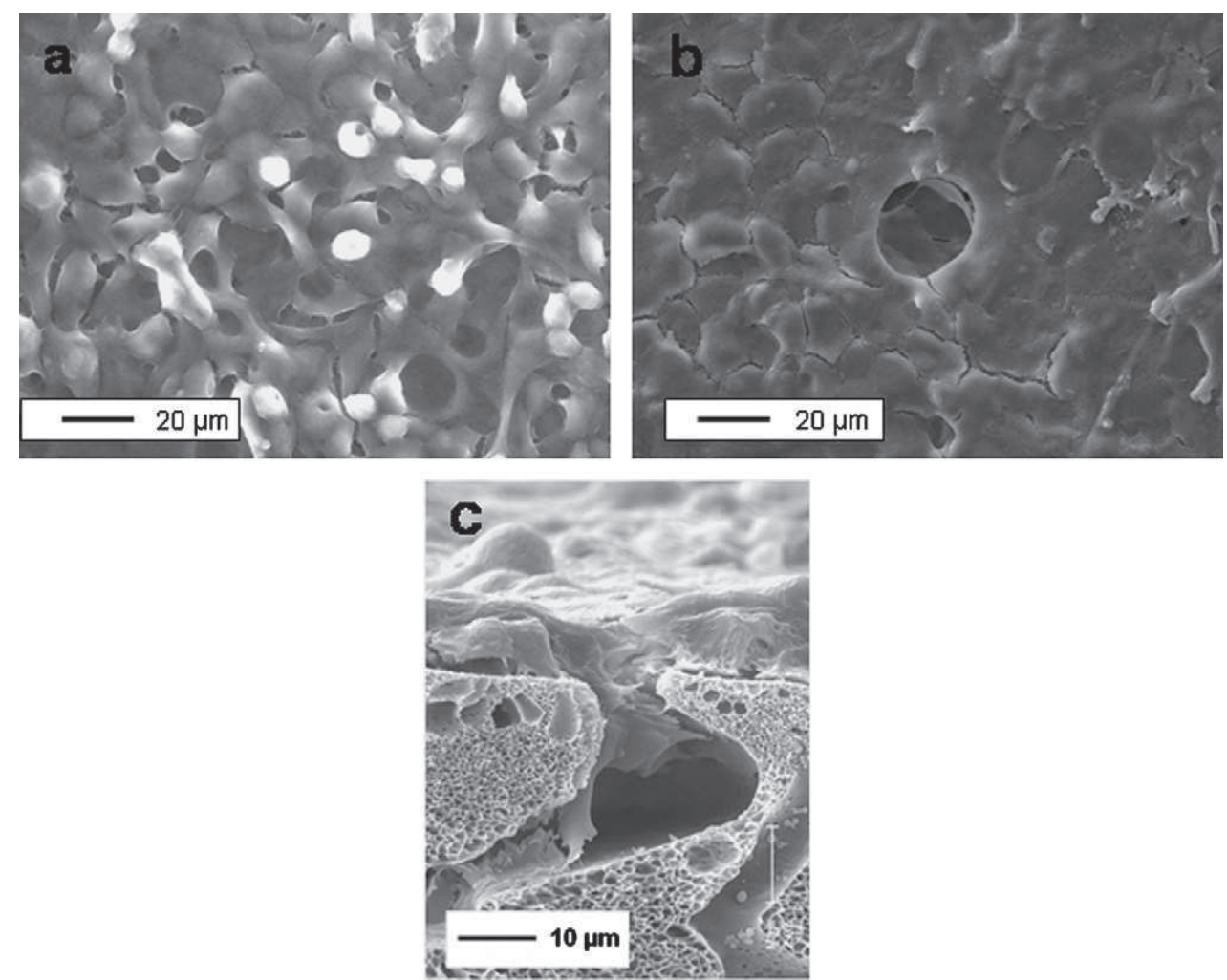

Fig. 4. ESEM observation of hepatic cells after 8 days of culture on: (a) membrane with single porosity, (b, c) membrane with double porosity level by over view and cross section respectively, both showing a macrochamber.

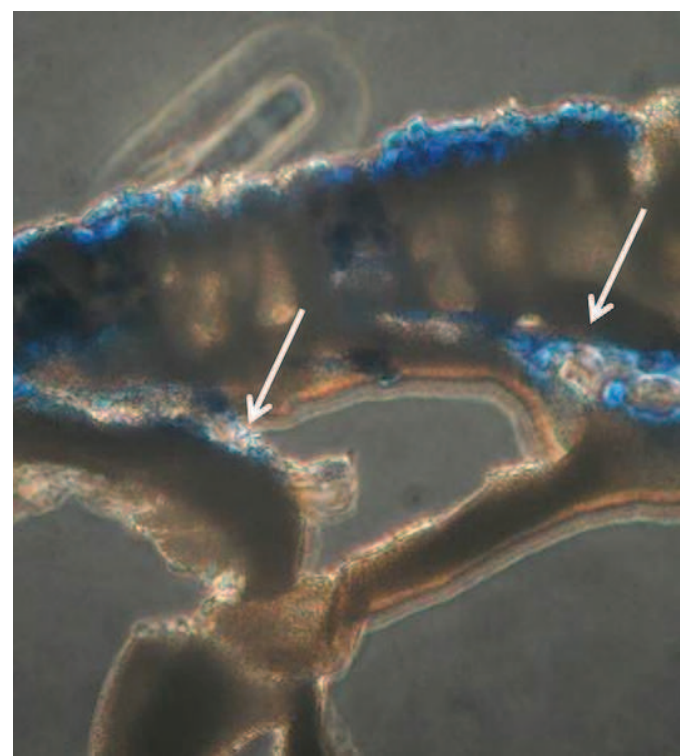

Fig. 5. Histological staining of a cross section of PSU membrane with double porosity showing cell invasion in macrochamber (arrow) $\times 100$.

determined by cell numeration, was observed after day 4 . These results, concerning the cell viability and proliferation, were confirmed by the Alamar Blue test. Data showed no significant difference between both types of membrane and with Thermanox (Fig. 6c).

On the membrane with double porosity, cells spread inside the macrochamber, as seen from ESEM view (Fig. 4b). Cross section of the membrane at high magnification (Fig. 4c) clearly showed that chambers were colonized by hepatic cells. In order to observe the inner structure of the membrane with double porosity, membrane cuts after 9 days of cell culture were stained with Methylene Blue (Fig. 5). The ESEM micrograph demonstrated effective cell invasion in the deeper parts of macrochambers, about $100 \mu \mathrm{m}$ from the contact surface.

\subsection{Cell functionality}

Hepatic cell functions were assessed by two parameters ammonia and albumin concentrations - which were measured in the supernatant, on days 2, 4, 8 and 9. The amounts of ammonia release were similar for the three materials at a level of $0.80 \mu \mathrm{mol} /$ $24 \mathrm{~h} / 10^{6}$ cells. No significant difference was noted during the culture period (Fig. 7a). Albumin release in the culture medium was significantly higher when $\mathrm{C} 3 \mathrm{~A}$ cells were grown on membrane with the double porosity in comparison to Thermanox $(p<0.05)$, whatever the time of culture. Such a difference is also observed between the double and single porosity membrane from day 2 to 9 , being significant at day $8\left(4.6 \mu \mathrm{g} / 24 \mathrm{~h} / 10^{6}\right.$ cells versus $4.3 \mu \mathrm{g} / 24 \mathrm{~h} / 10^{6}$ cells for membrane with double porosity and membrane with simple porosity, respectively) $(p<0.05)$ (Fig. 7b). Because the macrovoids' mouths are large enough to allow cells in, we consider that this difference in albumin concentration is not the result of a difference in permeability to proteins or other metabolites between the membrane and the control. In addition, albumin production was lower at day 2 in comparison with other time points, regardless the type of support. These data were consistent with the characteristics of the $\mathrm{C} 3 \mathrm{~A}$ cell line: they have been reported to secrete more albumin as they become confluent [14].

\section{Discussion}

The semi-permeable membrane is one of the essential components of BAL device as it acts as a selective barrier between the 

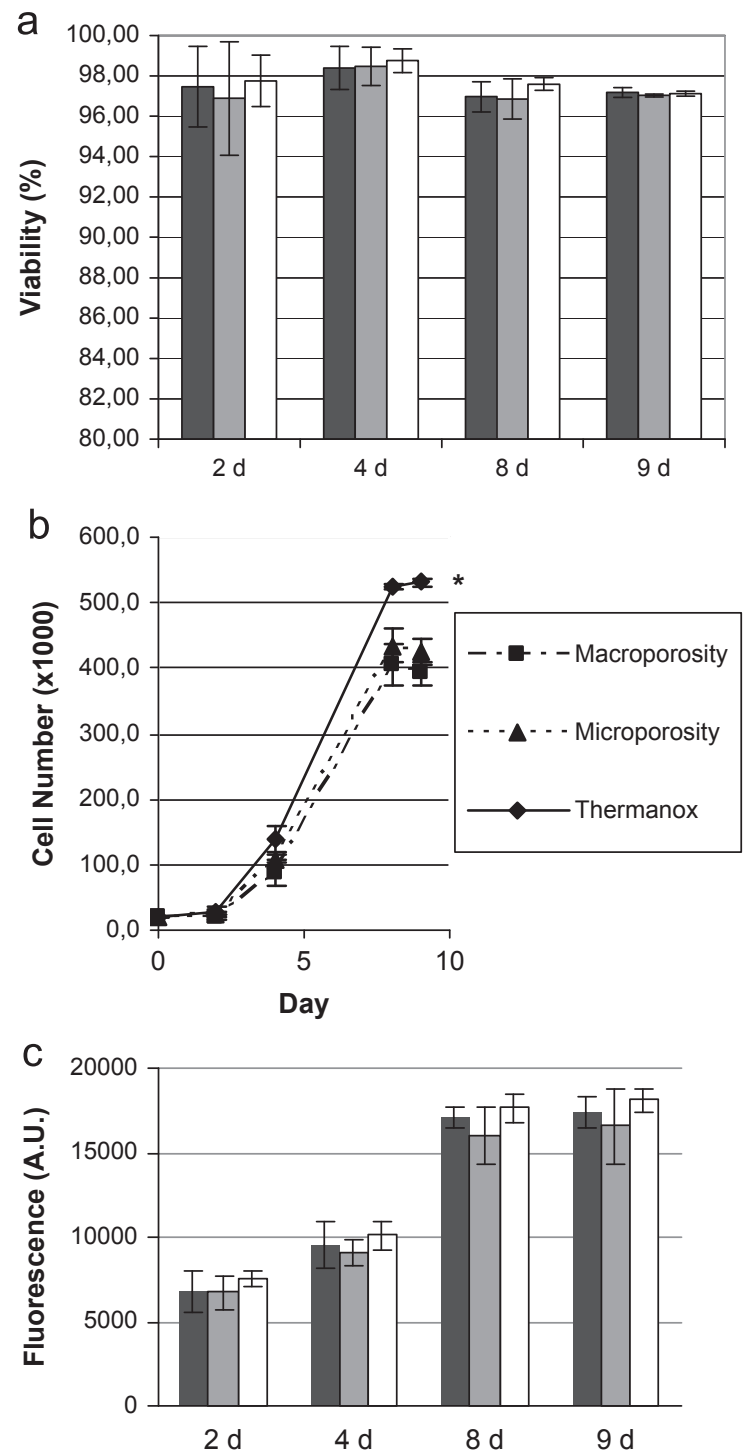

Fig. 6. Hepatic cell behavior on PSU membranes with double porosity, single porosity and Thermanox: (a) viability by LDH assay; (b) proliferation by cell numeration; (c) metabolic activity by Alamar Blue test. Black bars: membrane with double porosity; gray bar: membrane with single porosity; white bar: Thermanox. Error bars show standard deviation of nine measurements from three independent experiments. *Significantly different $(p<0.05)$ with Kruskal-Wallis non-parametric test.

patient's plasma or blood and liver tissue formed from heterologous or xenogenic hepatocytes. Ideally, membranes used as scaffold should present the following properties: (i) biocompatibility, dependent of the chemical composition and surface roughness, essential to initiate the liver tissue formation; (ii) structural $3 \mathrm{D}$ organization which may guide the development of growing tissue and favor cell metabolism and specific liver functions; and (iii) microporosity to selectively transfer oxygen and nutrients, remove cell catabolites, ensure effective detoxification functions and avoid immune responses.

Synthetic polymeric membranes can be modified in order to respond to selective filtration and biocompatibility properties for blood and liver tissue requirements. The chemical composition [15-17], the surface characteristics by grafting functional groups [18-21] or the modification of porosity and pore diameter of PSU membranes [22-25] are some of numerous strategies to improve mass transfers, humoral immune responses and to influence the hepatocyte behavior cultivated on these membranes.
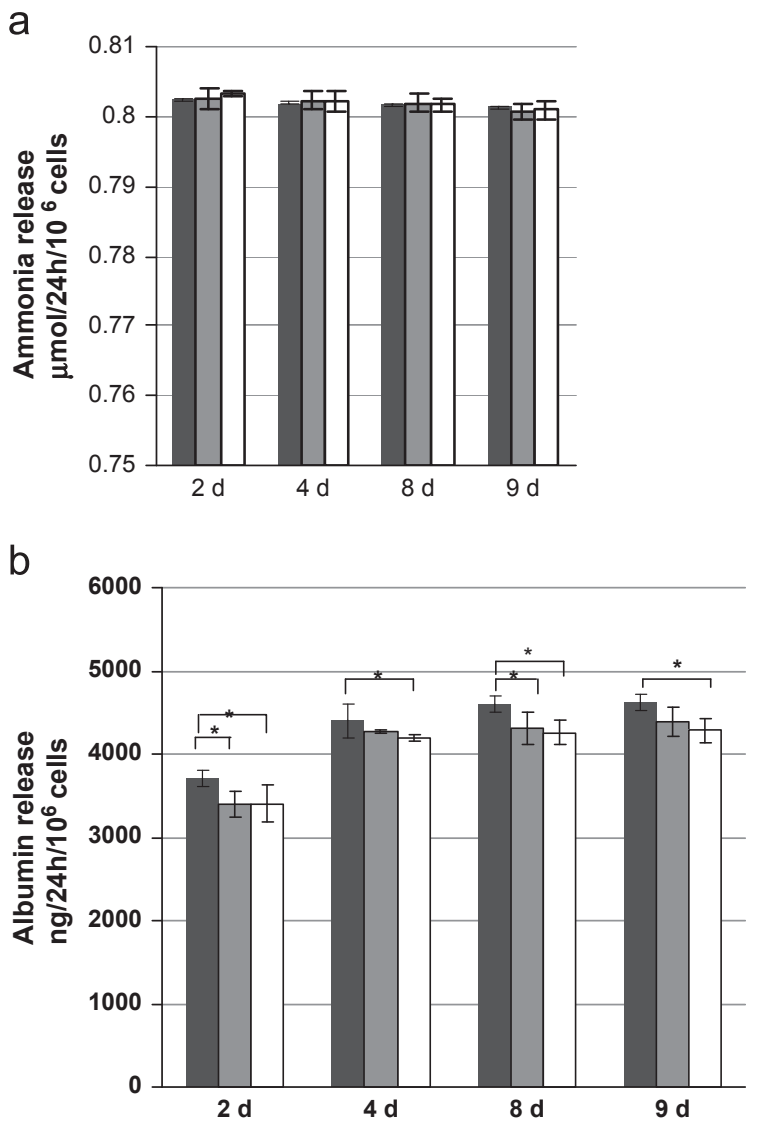

Fig. 7. Hepatic cell functionality on PSU membranes with double porosity, single porosity and Thermanox: (a) ammonia release; (b) albumin synthesis. Black bars: membrane with double porosity; gray bar: membrane with single porosity; white bar: Thermanox. Error bars show standard deviation of six measurements from two independent experiments. *Significantly different $(p<0.05)$ with KruskalWallis non-parametric test.

Here, we propose to manufacture and investigate a PSU membrane characterized by two porosity levels: a microporosity maximizing the diffusion and exchange of nutrients throughout the membrane wall and soluble mediators between the growing cells, and a macroporosity optimizing tissue function as it was described for bone in-growth [26].

The technique set up to obtain this double porosity was very delicate and did not change the native membrane properties. We seeded C3A cells, a hepatic cell line, on two types of porous membrane and followed the cell behavior over 9 days as a marker of polymeric membrane cytocompatibility. C3A cells were applied as a widely accepted cellular model for assessment of hepatocyte behavior. These cells were also used in the extracorporeal assist device system in a pilot-controlled trial (ELAD) [27].

The hydrophobic properties of PSU polymer are not ideal for cell adhesion and spreading in comparison with hydrophilic materials [6]. This drawback could be avoided by a precoating step with specific proteins, like collagen or fibronectin, which recovered the surface and increased the hydrophilic characteristic of PSU. In our case, the hydrophobic properties of PSU membranes were changed by a precoating step in completed medium culture before cell seeding, enabling the deposit of an active serum protein layer on the PSU surface. The data presented here confirmed a well organized monolayer of polygonal C3A cells on PSU membrane, whatever the porosity type, and was comparable to cell organization on standard tissue culture substrates, such as Thermanox. 
The cell numeration indicated no difference between the two types of PSU membranes: from day 2, C3A cells proliferated equally on PSU membranes with double porosity or with single one. The slowing down of growth between both PSU membranes and Thermanox was not due to cell death because the viability, measured by the LDH assay, was similar in the two conditions and superior to $96 \%$. This data was confirmed by the Alamar Blue test, a colorimetric assay used to quantify the cell viability and growth [28]. Then, our results confirmed the good cytocompatibility of PSU membranes, although C3A growth was more favorable on Thermanox, as its hydrophilic characteristic might let it expect [15].

The analysis of some hepatocyte functions showed that $\mathrm{C} 3 \mathrm{~A}$ cells maintained the ammonia and albumin release when cultivated on membrane with double porosity, compared to controls, i.e. membrane with single porosity and Thermanox support. The difference between albumin production rates on the two types of PSU membrane at day 8 might be a consequence of cell organization in macropores. The stuffy space of macrochambers could limit, under the static culture conditions employed here, the diffusion of mediators in the culture medium and concentrate secreted molecules near the hepatocytes. The tissue development in macrochamber might concentrate mitogens and hepatotrophic factors then enabling a stimulation of albumin secretion [29]. This hypothesis was reinforced by the ESEM observations which clearly showed the cell capacity to colonize the macrochambers during the culture period. Hepatocytes were spread on the macrochamber surfaces and invaded the 3D structure on about $70 \mu \mathrm{m}$ of depth.

In most cases, BAL devices use hollow fibers whose chemical, mechanical and morphological properties of membranes are directly associated to BAL safety and performance. In hollow fiber bioreactor systems, fibers provide luminal compartment for plasma or blood perfusion and the hepatocytes are grown in the extracapillary space, on the surface of the hollow fiber membrane, which generally presents a single level of porosity (systems ELAD, MELS, Oxy-HFB, LLS-HALSS) [30]. Cells organize in large aggregates or in tissue-like organoids in contact with fiber membrane. The membranes act as a barrier protecting cells from shear stress and avoiding direct contact with immune molecules, but could be a limiting factor to optimal exchanges [31]. The extracapillary space has to host large amounts of liver cells, ideally a mass of at least $20 \%$ of the normal liver, to recover an optimal functionality [32]. In all of these cases, the capacity for cell hosting is limited by the available void volume in the cartridge or in the lumen of the fibers. In contrast, the membrane with double porosity level described here presented an original internal structure to respond to this space constraint. Macrochambers may be a guide to the hepatocyte aggregate development, enabling high cell density in controlled sizes. The microporosity of macrochamber walls could assume bidirectional mass transfers and increase contact surface between cells and flow compartment.

In the context of development of bioartificial liver systems, C3a cell line is not the ultimate cell choice. The macrochambers of double porosity membrane could be an opportunity to overcome some limitations inherent to the in vitro culture of primary hepatocytes. These cells, considered as the most adequate model for applications in liver tissue engineering, are well known to lose their liver-specific functions when maintained in conventional culture conditions. A high degree of functionality was nevertheless obtained cultivating these cells in aggregates or in $3 \mathrm{D}$ in polyurethane foaming membranes [33,34]. The macrochambers in the PSU membrane could be a suitable model to guide the 3D primary hepatocyte organization while controlling the cell aggregate diameter.

Based on the encouraging biological data obtained with flat sheet membranes, and the real potential for cell colonization in the macrochambers, such membrane with double porosity level could be integrated in microfluidic biochip [35] or at larger scale, in flat membrane bioreactor to develop new cryopreservation methods or to supply liver failure [36,37]. In flat membrane bioreactor, it would thus be possible to combine high mass transfer properties due to diffusion and convection achieved under perfusion conditions, and high cell density offered by the macropore area.

\section{Conclusion}

In the present study, a membrane with double porosity level was formulated and characterized for an application in liver tissue engineering. The membrane appeared to be biocompatible and offer a 3D environment into its structure that can be colonized by hepatocytes, leading to a potentially high cell density. Cell toxicity was not observed and functions were maintained over 9 days. These encouraging results obtained with PSU membranes need now to be confirmed by hybrid liver support devices in tissue engineering.

\section{Acknowledgments}

The authors thank M. Jaffrin, University of Technology of Compiegne, France, for helpful discussion and comments on the manuscript and F. Nadaut for excellent technical assistance on analysis by SEM.

\section{References}

[1] S.K. Bowry, Dialysis membranes today, Int. J. Artif. Organs 25 (2002) 447-460.

[2] T. Sanaka, M. Koremoto, Selection guidelines for high-performance membrane, Contrib. Nephrol. 173 (2011) 30-35.

[3] L. De Bartolo, S. Salerno, E. Curcio, A. Piscioneri, M. Rende, S. Morelli, F. Tasselli, A. Bader, E. Drioli, Human hepatocyte functions in a crossed hollow fiber membrane bioreactor, Biomaterials 30 (2009) 2531-2543.

[4] K. Heilmann, T. Keller, Polysulfone: the development of a membrane for convective therapies, Contrib. Nephrol. 175 (2011) 15-26.

[5] S.K. Bowry, E. Gatti, J. Vienken, Contribution of polysulfone membranes to the success of convective dialysis therapies, Contrib. Nephrol. 173 (2011) $110-118$.

[6] L. De Bartolo, S. Morelli, A. Bader, E. Drioli, Evaluation of cell behaviour related to physico-chemical properties of polymeric membranes to be used in bioartificial organs, Biomaterials 23 (2002) 2485-2497.

[7] A. Urbani, S. Lupisella, V. Sirolli, S. Bucci, L. Amoroso, B. Pavone, L. Pieroni, P. Sacchetta, M. Bonomini, Proteomic analysis of protein adsorption capacity of different haemodialysis membranes, Mol. Biosyst. 8 (2012) 1029-1039.

[8] M. Hayama, K. Yamamoto, F. Kohori, T. Uesaka, Y. Ueno, H. Sugaya, I. Itagaki, K. Sakai, Nanoscopic behavior of polyvinylpyrrolidone particles on polysulfone/ polyvinylpyrrolidone film, Biomaterials 25 (2004) 1019-1028.

[9] A. Higuchi, K. Shirano, M. Harashima, B.O. Yoon, M. Hara, M. Hattori, K. Imamura, Chemically modified polysulfone hollow fibers with vinylpyrrolidone having improved blood compatibility, Biomaterials 23 (2002) 2659-2666.

[10] B. Carpentier, A. Gautier, C. Legallais, Artificial and bioartificial devices: present and future, Gut 58 (2009) 1690-1702.

[11] K.C. Rustad, M. Sorkin, B. Levi, M.T. Longaker, G.C. Gurtner, Strategies for organ level tissue engineering, Organogenesis 6 (2010) 151-157.

[12] K.M. Kulig, J.P. Vacanti, Hepatic tissue engineering, Transpl. Immunol. 12 (2004) 303-310.

[13] J.C. Remigy, X-ray tomography application to 3D characterization of membranes, in: Guell Carme, Ferrando Montserrat, Lopez Francisco (eds.), From Monitoring and Visualizing Membrane-Based Processes, WILEY-VCH Verlag GmbH \& Co. KGaA, Weinheim, 2009, pp. 209-228.

[14] J.H. Kelly, Permanent human hepatocyte cell line and its use in a liver assist device (LAD). US Patent 5, 290,684 dated March 1, 1994.

[15] H. Grant, C. Morgan, C. Henderson, G. Malsch, B. Seifert, W. Albrecht, T. Groth, The viability and function of primary rat hepatocytes cultured on polymeric membranes developed for hybrid artificial liver devices, J. Biomed. Mater. Res. 73A (2005) 367-375.

[16] A. Kostadinova, B. Seifert, W. Albrecht, G. Malsch, T. Groth, A. Lendlein, G. Altankov, Novel polymer blends for the preparation of membranes for biohybrid liver systems, J. Biomater. Sci. Polym. Ed. 20 (2009) 821-839.

[17] N. Krasteva, U. Harms, W. Albrecht, B. Seifert, M. Hopp, G. Altankov, T. Groth, Membranes for biohybrid liver support systems-investigations on hepatocyte attachment, morphology and growth, Biomaterials 23 (2002) 2467-2478. 
[18] L. De Bartolo, S. Morelli, L.C. Lopez, L. Giorno, C. Campana, S. Salerno, M. Rende, P. Favia, L. Detomaso, R. Gristina, R. d'Agostino, E. Drioli, Biotransformation and liver-specific functions of human hepatocytes in culture on RGD-immobilized plasma processed membranes, Biomaterials 26 (2005) 4432-4441.

[19] H.F. Lu, W.S. Lim, J. Wang, Z.Q. Tang, P.C. Zhang, K.W. Leong, S.M. Chia, H. Yu, H.Q. Mao, Galactosylated PVDF membrane promotes hepatocyte attachment and functional maintenance, Biomaterials 24 (2003) 4893-4903.

[20] X.J. Huang, D. Guduru, Z.K. Xu, J. Vienken, T. Groth, Blood compatibility and permeability of heparin-modified polysulfone as potential membrane for simultaneous hemodialysis and LDL removal, Macromol. Biosci. 11 (2011) 131-140.

[21] S. Salerno, A. Piscioneri, S. Laera, S. Morelli, P. Favia, A. Bader, E. Drioli, L. De Bartolo, Improved functions of human hepatocytes on NH3 plasma-grafted PEEK-WC-PU membranes, Biomaterials 30 (2009) 4348-4356.

[22] N. Krasteva, B. Seifert, W. Albrecht, T. Weigel, M. Schossig, G. Altankov, T. Groth, Influence of polymer membrane porosity on C3A hepatoblastoma cell adhesive interaction and function, Biomaterials 25 (2004) 2467-2476.

[23] S.L. Nyberg, T. Yagi, T. Matsushita, J. Hardin, J.P. Grande, L.E. Gibson, J.L. Platt, Membrane barrier of a porcine hepatocyte bioartificial liver, Liver Transplant. 9 (2003) 298-305.

[24] Q. Meng, G. Zhang, D. Wu, Hepatocyte culture in bioartificial livers with different membrane characteristics, Biotechnol. Lett. 26 (2004) 1407-1412.

[25] A. Gautier, A. Ould-Driss, M. Dufresne, P. Paullier, B. Von Harten, H.D. Lemke, C. Legallais, Hollow fiber bioartificial liver: physical and biological characterization with C3A cells, J. Membr. Sci. 341 (2009) 203-213.

[26] J.E. Davies, R. Matta, V.C. Mendes, P.S. Perri de Carvalho, Development, characterization and clinical use of a biodegradable composite scaffold for bone engineering in oro-maxillo-facial surgery, Organogenesis 6 (2010) 161-166.

[27] A.J. Ellis, R.D. Hughes, J.A. Wendon, J. Dunne, P.G. Langley, J.H. Kelly, G.T. Gislason, N.L. Sussman, R. Williams, Pilot-controlled trial of the extracorporeal liver assist device in acute liver failure, Hepatology 24 (1996) 1446-1451.

[28] R.G. Nakayama, M.C. Caton, M.P. Nova, Z. Parandoosh, Assessment of the Alamar Blue assay for cellular growth and viability in vitro, J. Immunol. Methods 204 (1997) 205-208.

[29] Y.T. Hou, H. Ijima, S. Matsumoto, T. Kubo, T. Takei, S. Sakai, K. Kawakami, Effect of a hepatocyte growth factor/heparin-immobilized collagen system on albumin synthesis and spheroid formation by hepatocytes, J. Biosci. Bioeng. 110 (2010) 208-216.

[30] J.K. Park, D.H. Lee, Bioartificial liver systems: current status and future perspective, J. Biosci. Bioeng. 99 (2005) 311-319.

[31] Y.T. Ding, X.L. Shi, Bioartificial liver devices: perspectives on the state of the art, Front Med. 5 (2011) 15-19.

[32] R.A.F.M. Chamuleau, Future of bioartificial lievr support, World J. Gastrointest. Surg. 30 (2009) 21-25.

[33] A. Higuchi, M. Satoh, K. Kobayashi, C.S. Cho, T. Akaike, T.M. Tak, S. Egashira, Y. Matsuoka, S.H. Natori, Albumin and urea production by hepatocytes cultured on polyurethane foaming membranes coated with extracellular matrix, J. Membr. Sci. 280 (2006) 983-989.

[34] M.G. Baron, W.M. Purcell, S.K. Jackson, S.F. Owen, A.N. Jha, Towards a more representative in vitro method for fish ecotoxicology: morphological and biochemical characterization of three-dimensional spheroidal hepatocytes, Ecotoxicology 21 (2012) 2419-2429.

[35] A. Ould Dris, P. Paullier, L. Griscom, C. Legallais, E. Leclerc, Analysis of the mass transfers in an artificial kidney microchip, J. Membr. Sci. 352 (2010) 116-125.

[36] M. Maringka, S. Giri, A. Bader, Preclinical characterization of primary porcine hepatocytes in a clinically relevant flat membrane bioreactor, Biomaterials 31 (2010) 156-172.

[37] S. Giri, U. Weingartz, K. Nieber, A. Acikgöz, A. Bader, Cryopreservation of primary porcine liver cells in an organotypical sandwich model in a clinically relevant flat membrane bioreactor, Biotechnol. Lett. 32 (2010) 765-771. 